\title{
THE LEADING CAUSES AND POTENTIAL CONSEQUENCES OF OCCUPATIONAL STRESS: A STUDY OF IRISH TRAINEE ACCOUNTANTS
}

\author{
Teresa Kelly ${ }^{1}$ \\ Ernst \& Young \\ and Mary Barrett \\ National University of Ireland, Galway
}

\begin{abstract}
$\mathrm{T}$

This study examines the root causes of occupational stress in Irish trainee accountants and investigates the relationship between occupational stress, job satisfaction and turnover intentions of Irish trainee accountants. Findings suggest that exam pressure, role conflict, role ambiguity, qualitative role overload, quantitative role overload and a dominant supervisor are the most common sources of occupational stress experienced by Irish trainee accountants. Whilst many of the job stressors identified were independently found to be significantly positively related to job-related tension (occupational stress), the combination of role overload (both qualitative and quantitative) and role ambiguity is found to significantly impact on job-related tension. Furthermore, role ambiguity and career development concerns were found to have a combined negative impact on job satisfaction, and job dissatisfaction combined with role conflict significantly impacted on turnover intentions. The implications for employers and accounting membership bodies are discussed in this paper along with opportunities for further research.
\end{abstract}

\section{INTRODUCTION}

Stress has been defined as 'any force that puts a psychological or physical factor beyond its range of stability, producing a strain within the individual' (Cooper, Cooper and Eaker, 1988, p. 12). Libby (1983, pp. 372-373) suggests that stress results from both the quantitative and qualitative demands of a task, which can 
Kelly and Barrett

be 'mediated by perceived control and predictability'. Quantitative demands refer to the 'level of effort' required in undertaking a task, whilst 'qualitative demands include physical/psychological discomfort caused by the decision environment and, more importantly, the stakes, incentives, or potential costs and benefits of any action selected' (Libby, 1983, pp. 372-373).

Occupational stress has in the past been the focus of a plethora of studies (e.g. Rizzo, House and Lirtzman, 1970; Gaertner and Ruhe, 1981; Choo, 1986). The accounting profession is generally considered to be a stressful profession (Gaertner and Ruhe, 1981; Smith and Everly, 1990; Sanders and Fulks, 1995) and has been referred to in the past as a 'pressure cooker environment' (Gaertner and Ruhe, 1981, p. 69). Carcello, Copeland, Hermanson and Turner (1991) found stress/pressure to be one of the main facets of public accounting that practitioners liked least about the profession. While some stress is normal and can generate positive effects, e.g. motivation of employees to attain goals (Gavin and Dileepan, 2002), excessive stress can have negative repercussions for both organisations and individuals (Collins and Killough, 1989). From an organisational perspective, stress has been found to contribute to job dissatisfaction, lower job performance, absenteeism and employee turnover (Gavin and Dileepan, 2002). The many undesirable consequences of excessive stress signal the importance of research in this area.

Trainee accountants are more susceptible to occupational stress than any other group in an accountancy firm (Gaertner and Ruhe, 1981; Sanders and Fulks, 1995) and thus represent an important focus for occupational stress research. Sweeney and Boyle (2005) investigated the relationships between levels of job satisfaction, perceived supervisory actions and turnover intentions of Irish trainee accountants, but did not consider occupational stress as a potential antecedent of job dissatisfaction. The principal objectives of this study are, firstly, to examine the sources of occupational stress of trainee accountants in Ireland and, secondly, to model the fundamental relationships between occupational stress, job satisfaction and turnover intentions.

This paper is organised as follows: the next section reviews academic literature in the area and develops a number of hypotheses to be examined in this study. The following sections address the research methodology employed in the study, the findings, and an analysis of the findings. Finally, a discussion of the conclusions and implications of the study are presented where limitations of the study and scope for future research in the area are briefly outlined.

\section{LITERATURE REVIEW AND HYPOTHESES DEVELOPMENT}

\section{Job Stressors: Sources of Occupational Stress}

Stress in the workplace has been primarily regarded as resulting from job stressors. Stressors are 'those events occurring in the environment or in the body that make an emotional or task demand on the individual' (Hobfoll, 1988, p. 16). Increases in job stressors are deemed to act on individuals to produce job stress (French and Caplan, 1973). Several job stressors have been documented in the occupational 
stress literature, e.g. role conditions, job qualities, work relations, career progress and lack of challenges.

\section{Job Stressors among Trainee Accountants}

Gaertner and Ruhe (1981), in their research, found that junior staff accountants experienced more stress than other groups within accounting firms. The junior staff respondents reported the greatest levels of stress resulting from role underload, role ambiguity, career progress concerns and having insufficient opportunities to partake in decisions that ultimately have an effect on them (Gaertner and Ruhe, 1981). Sanders and Fulks (1995) also reported junior accountants suffered the greatest level of 'psychosomatic distress' in an accounting firm. Their study indicated that the main job stressors acting on junior accountants were role ambiguity, role conflict, qualitative overload, job scope and career progress.

This paper aims to examine the sources of occupational stress in trainee accountants in Ireland. Given the impracticability of examining a large number of variables, this study embraces only a certain number of variables of potential relevance to trainee accountants. These are outlined below.

\section{Role Stress}

'One source of stress regularly encountered by most individuals in work settings is role stress' (Fisher, 2001, p. 143). Role stress consists of two constructs: role ambiguity and role conflict (Kahn, Wolfe, Quinn, Snoek and Rosenthal, 1964). Role conflict refers to 'the presence of incompatible role pressures' (Bamber, Snowball and Tubbs, 1989, p. 287). An employee experiences role conflict when he/she 'must choose to do one thing over another and feels uneasy' about the situation (Milbourn, 2006, p. 44). Role ambiguity has been defined as the 'lack of clarity surrounding a person's job authority, responsibility, task demands, and work methods' (Milbourn, 2006, p. 44). '[A] job is ambiguous [if] the worker has unclear work goals, procedures, and responsibilities and may be uncertain about his or her authority' (Milbourn, 2006, p. 44). Role conflict and role ambiguity have been found to be related to job-related tension in non-accounting firms (Lysonski, 1985). [Note: prior literature have used the terms 'job stress', 'occupational stress' and 'job-related tension' interchangeably; this study defines job-related tension as occupational stress.] Senatra (1980) and Rebele and Michaels (1990) carried out studies among independent auditors and established statistically significant relationships between role conflict and job-related tension. No significant correlation between role ambiguity and job-related tension was identified in either of these studies. Based on previous research, the following hypotheses specific to Irish trainee accountants are put forth:

$\mathrm{H}_{1}$ : High levels of role conflict will be positively associated with job-related tension in Irish trainee accountants.

$\mathrm{H}_{2}$ : High levels of role ambiguity will be positively associated with job-related tension in Irish trainee accountants. 
Job Quality

Job quality refers to both role overload and role underload (Ehlen, Cluskey and Rivers, 2000). Both role overload and role underload have quantitative and qualitative dimensions. Quantitative role overload stress arises where an individual is assigned 'too great a volume of work to accomplish in the allocated time' whereas qualitative role overload stress occurs where 'job requirements exceed the individual's ability or skill level' (Sanders and Fulks, 1995, p. 46). Contrastingly, quantitative role underload stress occurs where an individual is assigned too little work (Milbourn, 2006). Qualitative role underload stress arises where job requirements are too easy, i.e. where 'job assignments are not personally challenging' (Larson, 2004, p. 1126) and 'do not require full use of skills and abilities' (Gavin and Dileepan, 2002, p. 53). Numerous researchers have reported a significant relationship between role overload and occupational stress in members of the accounting profession (Collins and Killough, 1989; Haskins, Baglioni and Cooper, 1991; Collins and Killough, 1992; Cluskey and Vaux, 1997; Gavin and Dileepan, 2002). Gaertner and Ruhe (1981) reported a relationship between stress in junior accountants and feelings of being underused at work. Thus, low job scope - where a job is unimportant, lacks variety or is not demanding enough for the employee - is a potential source of job-related stress (Collins and Killough, 1992). Xie and Johns (1995) reported a strong association between stress and low job scope. Based on the previous cited studies which have linked the existence of either role overload or role underload (including low job scope) to occupational stress, a third hypothesis is postulated:

$H_{3}$ : High levels of role overload/role underload will be positively associated with job-related tension in Irish trainee accountants.

\section{Career Progress}

Career progress, in terms of job insecurity and under-promotion, has also been recognised in the literature as a potential source of occupational stress for accountants (Gavin and Dileepan, 2002) and junior accountants (Sanders and Fulks, 1995). In addition, Gaertner and Ruhe (1981) discovered that ambiguity regarding junior accountants' future careers is a primary source of occupational stress. Thus, it is postulated that:

\section{$\mathrm{H}_{4}$ : Career progress concerns will be positively associated with job-related tension in Irish trainee accountants.}

\section{The Supervisor/Manager}

Larson (2004) found that supervisors who 'rule with an iron hand' and who rarely allow participation in decision making can contribute to severe stress problems for subordinates (Larson, 2004, p. 1127), yet Siegel and Reinstein (2001) found that mentoring by supervisors can play an important role in reducing stress levels. Thus, varying supervisory styles are likely to have an impact on stress levels of subordinates and the following hypotheses are postulated: 
$\mathrm{H}_{5}$ : A dominant and demanding supervisor/manager will be positively associated with job-related tension in Irish trainee accountants.

$\mathrm{H}_{6}$ : A passive supervisor/manager who gives little feedback to Irish trainee accountants will be positively associated with job-related tension in Irish trainee accountants.

Exam Pressure

Collins and Killough (1989) found when surveying qualified accountants that a conflict existed between their work and family due to insufficient time available for leisure (family-oriented) activities. It is likely that trainee accountants would also experience this conflict, which may be exacerbated by the additional requirement to spend time outside of work hours attending courses and studying for examinations. Previous studies have not examined this potential variable; thus, a seventh hypothesis is proposed:

$\mathbf{H}_{7}$ : Exam pressure will be positively associated with job-related tension in Irish trainee accountants.

\section{Consequences of Occupational Stress: Job Outcomes}

The impact of occupational stress on variables such as job satisfaction and turnover intentions has stimulated considerable research in the behavioural accounting literature (e.g. Fogarty, Singh, Rhoads and Moore, 2000). In this study we will examine a number of potential sources of occupational stress but the bulk of prior literature examining the impact of occupational stress has operationalised stress as role conflict and role ambiguity (e.g. Senatra, 1980; Rebele and Michaels, 1990; Fisher, 2001). Role conflict and role ambiguity have been found to be related to dysfunctional job outcomes and job-related attitudes: lower job satisfaction and higher job-related tension (Lysonski, 1985).

\section{Job-Related Tension}

The relationships between role conflict and ambiguity and job-related tension have been included in the current study as $\mathrm{H}_{1}$ and $\mathrm{H}_{2}$.

\section{Job Satisfaction}

'Job satisfaction can be defined as an individual's affective reaction to his or her work environment' (Dole and Schroeder, 2001, p. 235). 'Job dissatisfaction results when a job, for whatever reason, fails to fulfil job-related values' (Fisher, 2001, p. 148). The bulk of previous literature has reported an inverse relationship between occupational stress and job satisfaction (Burke, 1976; Rebele and Michaels, 1990; Snead and Harrell, 1991; Gregson and Wendell, 1994; Fisher, 2001; Gavin and Dileepan, 2002). Senatra (1980) found that increased role ambiguity led to increased senior auditor job dissatisfaction. However, Senatra (1980) did not find a significant relationship between role conflict and job satisfaction; thus there have been conflicting results in the literature reviewed. Based on prior findings, the following hypotheses specific to Irish trainee accountants are put forth: 
Kelly and Barrett

$\mathrm{H}_{8}$ : High levels of role conflict will be negatively associated with job satisfaction in Irish trainee accountants.

$\mathrm{H}_{9}$ : High levels of role ambiguity will be negatively associated with job satisfaction in Irish trainee accountants.

\section{Turnover Intentions}

Prior research has consistently found an inverse relationship between job satisfaction and an employee's turnover intentions (Harrell, Chewning and Taylor, 1986; Rasch and Harrell, 1990; Dole and Schroeder, 2001; Sweeney and Boyle, 2005). Turnover intentions represent the desire to leave one's current employment and, combined with other factors, can provide a viable indication of subsequent actual turnover (Arnold and Feldman, 1982). Trainee accountants often work within a pyramidal structure, where some turnover is deemed to be natural and necessary in order to make room for new trainees. Employers, however, invest significantly in training young accountants (Sorensen, Rhode and Lawler, 1973) and excessive turnover can be very costly (Hyndman, 1994). Generally, turnover is viewed as 'the natural conclusion to a state of extreme occupational dissatisfaction' (Cluskey and Vaux, 1997, p. 27). Based on previous research, it is postulated that:

$H_{10}$ : Job satisfaction will be negatively associated with turnover intentions in Irish trainee accountants.

\section{RESEARCH METHOD}

\section{Choice of Data Collection Method}

A questionnaire was deemed to be the most appropriate method of data collection for this study as it allowed for data to be collected from a large population in an economical and efficient manner. The questionnaire was constructed by combining a number of well-established models for measuring stress and its outcomes from the literature (Ivancavich and Matteson, 1980; Gmelch, Lovich and Wilke, 1984; Hoppock, 1935; Donnelly, Quirin and O'Bryan, 2003) with a number of new constructs being added for variables not previously examined in this context, for example exam pressure and the role of a dominant or passive supervisor on jobrelated tension.

The questionnaire (which had previously been pilot tested) was distributed to trainee accountants attending lectures in preparation for professional accounting examinations in Dublin and Galway. Additionally, the questionnaire was circulated to trainee accountants at medium-sized firms in Ireland. In all, 148 questionnaires were distributed and 116 usable responses were returned. Relevant extracts from the questionnaire for this paper are included in the appendix.

\section{Analysis of Respondents}

Table 1 provides an analysis of the respondents based on gender, type, size of practice and industry sector. 
TABLE I: DEMOGRAPHICS OF RESPONDENTS

\begin{tabular}{llc}
\hline \multicolumn{1}{c}{ Variable } & Number & $\%$ \\
\hline Gender & & \\
Male & 44 & 37.9 \\
Female & 72 & 62.1 \\
Type & & \\
Practice & 63 & 54.3 \\
Industry & 53 & 45.7 \\
Size of practice & & \\
Big 4 & 18 & 15.5 \\
Non big 4 & 45 & 38.8 \\
Industry sector & & \\
Financial services & 29 & 25.0 \\
Other & 24 & 20.7 \\
\hline
\end{tabular}

\section{Variable Measures}

Role conflict and role ambiguity were measured using a modified version of the Role Stress Scale developed by Rizzo et al. (1970) (Section B of questionnaire extract in the appendix). This measure consists of fourteen items: the first six items relate to role ambiguity and the final eight items relate to role conflict. The minor alterations made to the items in the questionnaire by Gregson, Wendell and Aono (1994) to make them more relevant to accountants were adopted in this study. Respondents were required to respond to each role item, signifying the degree to which the condition existed for them, on a five-point Likert scale where $1=$ very false and $5=$ very true. This fourteen-item scale is the most widely used measure of role ambiguity and conflict (Gregson et al., 1994). Gregson et al. (1994) tested the psychometric properties of both measures (role ambiguity and role conflict) and found that both are satisfactory measures of two separate and distinct role constructs. The items that measured role ambiguity were reverse scored so that higher values indicated a higher degree of ambiguity.

Role overload (qualitative) and career progress concerns were measured using items drawn from the Ivancavich and Matteson (1980) survey (Section D of questionnaire extract in the appendix). The first four items in Section $\mathrm{D}$ of the questionnaire measure role overload (qualitative) while items 9-13 measure career progress concerns. The respondents were required to indicate the frequency with which the condition described is a source of stress using a seven-point Likert scale where $1=$ if the condition described is never a source of stress and $7=$ if it is always a source of stress.

This study used a questionnaire developed by Gmelch et al. (1984) and used by Reichel and Neumann (1993) to measure quantitative role overload (Section D of questionnaire extract in the appendix - items 5, 6, 7, 8 and 15). Again, respondents were required to indicate the frequency with which the condition described is a 
Kelly and Barrett

source of stress using a seven-point Likert scale where $1=$ if the condition described is never a source of stress and $7=$ if it is always a source of stress.

The authors designed a two-item construct to measure role underload (Section $\mathrm{D}$ of questionnaire extract in the appendix). One item - 'I feel that I have too light a workload' - was designed to measure quantitative role underload. The other item - 'My assigned tasks are sometimes too easy and/or unchallenging/ undemanding and thus I tend to get bored easily at work' - was designed to measure qualitative role underload. Respondents were required to signify the frequency with which the conditions described are a source of stress using a seven-point Likert scale, consistent with previous construct measures.

The authors designed a two-item construct to determine if the characteristics of the trainee accountant's supervisor/manager are a source of stress for the trainee (Section D of questionnaire extract in the appendix - items 18 and 19). One item was designed to determine if a dominant supervisor is a source of stress for the trainee accountant. The other item was designed to establish if a passive supervisor who gives little feedback to the trainee accountant is a source of stress.

The authors also designed a two-item construct to measure exam pressure (Section D of questionnaire extract in the appendix). The two items were 'I am undertaking lectures in the evenings and/or at weekends which interfere with other activities' and 'Studying for exams interferes with other activities (family, recreation, etc.)'

Respondents were required to complete Hoppock's (1935) measure of job satisfaction, an instrument previously validated by McNichols, Stahl and Manley (1978) (Section G of questionnaire extract in the appendix). This instrument has frequently been used as a measure of job satisfaction (e.g. Rasch and Harrell, 1990; Dole and Schroeder, 2001). The instrument consists of four questions that test respondents' job satisfaction levels, each of which allows for seven possible responses. The average of responses to the questions was used to calculate an overall job satisfaction score for each individual. A score of 1 indicates low job satisfaction while a score of 7 indicates high job satisfaction.

Donnelly et al. (2003) developed and utilised a scale to assess turnover intentions. It consists of three items which assesses the respondents' immediate turnover intentions (within two years), middle-term turnover intentions (within five years) and long-term intentions (until retirement). The current study used this scale but the measurement of long-term intentions was changed from retirement to ten years to make it more realistic for trainee accountants (Section F of questionnaire extract in the appendix). The items were measured using a seven-point Likert scale where 1 $=$ strongly disagree and 7 = strongly agree. Items were reverse scored so that higher values indicated a higher degree of turnover intent.

The authors used a job-related tension instrument developed by Lysonski (1985) and adapted by Rebele and Michaels (1990) to measure job-related stress in this study (Section A of questionnaire extract in the appendix). This job-related tension instrument, consisting of eight questions, is an overall measure of psychological tension or stress linked to stress at work. The respondents were required to indicate the effect their job had on their health using a six-point Likert scale where 
$1=$ strongly disagree and $6=$ strongly agree. A job-related tension score for each individual was calculated as the average of the responses to the eight questions.

\section{Reliability of Scales}

Each of the scales included in the study were tested for their internal consistency to assess the degree to which the component items in the scales were all measuring the same underlying attribute (Pallant, 2007), consistent with prior literature (Cluskey and Vaux, 1997; Dole and Schroeder, 2001; Donnelly et al., 2003; Fisher, 2001; Lysonski, 1985; McNichols et al., 1978; Smith, Everly and Johns, 1993; Snead and Harrell, 1991). Cronbach's (1951) coefficient alpha was used where an average correlation between all items that make up the scale was provided. Cronbach alpha values can range between 0 and 1, with the higher value indicating higher reliability. Pallant (2007) indicates that the ideal alpha coefficient of a scale should be above 0.7 but values can differ depending on the size of the scale, where lower values of 0.5 are common with scales of fewer than ten items. Briggs and Cheek (1986, p.115) further suggest that where short scales, of fewer than ten items, are used the mean inter-item correlation should be reported as a measure of reliability where the optimal range is between 0.2 and 0.4 ; anything above 0.5 indicates that the construct measured was too specific. Where items were 'negatively worded' these were reversed before checking for reliability. Table 2 outlines the Cronbach alphas and mean inter-item correlations for each of the scales applied in the study. The Cronbach alphas reported demonstrate very good internal consistency for all measures. The mean inter-item correlation for career development and exam pressure, in particular, scored highly ( 0.71 and 0.788 respectively), indicating that the construct measured was too specific. No measures of reliability were calculated for role underload or the impact of a passive or dominant supervisor as in each case only one construct was developed. The results, however, have been incorporated in this study with suggestions for further expansion of these constructs in future research.

TABLE 2: RELIABILITY OF SCALES

\begin{tabular}{llll}
\hline \multicolumn{1}{c}{ Scale } & \multicolumn{1}{c}{$\begin{array}{c}\text { Cronbach } \\
\text { Alpha }\end{array}$} & $\begin{array}{c}\text { Number of } \\
\text { Items in Scale }\end{array}$ & $\begin{array}{c}\text { Mean Inter-Item } \\
\text { Correlation }\end{array}$ \\
\hline Job-related tension & 0.882 & 8 & 0.485 \\
Role ambiguity & 0.829 & 6 & 0.450 \\
Role conflict & 0.836 & 8 & 0.388 \\
Role overload - qualitative & 0.878 & 4 & 0.647 \\
Role overload - quantitative & 0.868 & 5 & 0.570 \\
Career development & 0.923 & 5 & 0.710 \\
Exam pressure & 0.880 & 2 & 0.788 \\
Turnover intentions & 0.760 & 3 & 0.590 \\
Job satisfaction & 0.878 & 4 & 0.664 \\
\hline
\end{tabular}


Kelly and Barrett

\section{Additional Comments}

Space was provided at the end of the questionnaire to enable respondents to make voluntary, unstructured comments on job problems or stress in their work (Section $\mathrm{H}$ of questionnaire extract in the appendix).

\section{Statistical Tests}

The data were input onto a spreadsheet and subsequently imported into SPSS (Statistical Package for the Social Sciences). SPSS allowed the authors to conduct a number of statistical tests. Statistical tests can be categorised as parametric tests and non-parametric tests. Parametric tests are generally used for interval data that is normally distributed. Parametric tests are deemed to be more powerful and efficient than non-parametric tests (Cooper and Emory, 1995) as non-parametric tests can sometimes fail to detect differences between groups that actually exist. The data in this study are primarily ordinal in nature and thus would deem that non-parametric tests should be used; however, it is not uncommon to treat ordinal variables as intervals because the advantages of using parametric tests are great and the error that is likely to occur would be deemed negligible (Labovitz, 1970). Prior studies in this area have also employed parametric tests and, thus, consistent with this, parametric tests including ANOVA tests, $t$-tests and correlation analysis were employed in this study. Non-parametric tests were also undertaken, the results of which are largely consistent with their parametric counterparts, differences being reported where they arise. Regression analysis was also used to evaluate the combined impact of a number of identified variables on job-related tension, job satisfaction and turnover intentions. Multiple regression and step-wise regression have been employed to explore the interrelationship between the identified variables (Pallant, 2007).

\section{FINDINGS}

\section{Job Stress Scores}

The average responses for each job stress variable ranging on a scale from 1 to 7 show that exam pressure is considered to be the most stressful of variables (mean of 5.14) with role underload (quantitative) scoring as the least stressful variable (mean of 2.41). Role stress scores for each of the individual role stress variables (role conflict and role ambiguity) were calculated using a five-point Likert scale. These were then transformed to a seven-point scale in order to aid comparability with the other job stress variables being studied. The mean role stress scores in the current study using a seven-point scale were 4.03 and 3.65 for role conflict and role ambiguity respectively. In order to compare contribution of various sources of stress, mean item scores were ranked (Table 3 ). The five highest mean scores were for exam pressure, role conflict, role ambiguity, role overload (qualitative) and role overload (quantitative). The five lowest mean scores were for a dominant supervisor, career development, a passive supervisor, role underload (qualitative) and role underload (quantitative). 


\begin{tabular}{lc}
\multicolumn{2}{l}{ TABLE 3: MEANS OF JOB AND ROLE STRESS } \\
\multicolumn{1}{c}{ VARIABLES USING A SEVEN-POINT SCALE } \\
\hline \multicolumn{1}{c}{ Variable } & Mean \\
\hline Exam pressure & 5.14 \\
Role conflict & 4.03 \\
Role ambiguity & 3.65 \\
Role overload - qualitative & 3.44 \\
Role overload - quantitative & 3.39 \\
Dominant supervisor & 3.27 \\
Career development & 3.04 \\
Passive supervisor & 2.87 \\
Role underload - qualitative & 2.72 \\
Role underload - quantitative & 2.41 \\
\hline
\end{tabular}

\section{Testing of Individual Hypotheses}

Hypothesised relationships were tested by Pearson's product-moment correlations. As shown in Table 4, role conflict was positively correlated (significant at the 0.01 level) with job-related tension $(r=0.322)$. Role ambiguity was also positively correlated (significant at the 0.01 level) with job-related tension $(r=0.307)$. Thus, the relationships specified in $\mathrm{H}_{1}$ and $\mathrm{H}_{2}$ were supported.

A moderately strong positive relationship was observed between role overload (quantitative and qualitative) and job-related tension $(r=0.580$ and $r=0.609$ respectively), significant at the 0.01 level (Table 4). No support exists for the hypothesised relationship between role underload (quantitative and qualitative) and job-related tension due to a lack of statistical significance (Table 4). Thus, the relationship between role overload and job-related tension in $\mathrm{H}_{3}$ is supported but the relationship between role underload and job-related tension in $\mathrm{H}_{3}$ is not supported.

The hypothesised relationship between career progress concerns and job-related tension was supported although the relationship was weak $(r=0.275)$, significant at the 0.01 level (Table 4). Thus, the relationship specified in $\mathrm{H}_{4}$ is supported.

The results portrayed a moderately strong positive relationship between a dominant supervisor and job-related tension $(r=0.534)$, significant at the 0.01 level (Table 4$)$, thereby supporting $\mathrm{H}_{5}$. A positive but weak correlation $(r=0.239)$ was identified between a passive supervisor and job-related tension, significant at the 0.01 level (Table 4 ), thereby supporting $\mathrm{H}_{6}$.

A positive relationship between exam pressure and job-related tension was observed $(r=0.364)$, significant at the 0.01 level, thus supporting $\mathrm{H}_{7}$. The results from Spearman's rank order correlations largely support the findings of the Pearson Correlation displayed in Table 4 , with role ambiguity ranking above role conflict $(r=0.343$ role ambiguity; $r=0.285$ role conflict). 
Kelly and Barrett

\begin{tabular}{|c|c|}
\hline Variable & Job-Related Tension \\
\hline Role overload - qualitative & $0.609 * *$ \\
\hline Role overload - quantitative & $0.580 *$ \\
\hline Dominant supervisor & $0.534 *$ \\
\hline Exam pressure & $0.364 *$ \\
\hline Role conflict & $0.322 *$ \\
\hline Role ambiguity & $0.307 *$ \\
\hline Career development & $0.275^{*}$ \\
\hline Passive supervisor & $0.239 *$ \\
\hline Role underload - qualitative & 0.040 \\
\hline Role underload - quantitative & -0.020 \\
\hline
\end{tabular}

* Correlation is significant at the $0.0 \mathrm{I}$ level (I-tailed).

Role conflict was found to be negatively correlated with job satisfaction $(r=-0.352)$, significant at the 0.01 level, providing support for $\mathrm{H}_{8}$. A negative relationship was also observed between role ambiguity and job satisfaction $(r=-0.481)$, significant at the 0.01 level, thereby providing support for $\mathrm{H}_{9}$ (Table 5).

\begin{tabular}{|c|c|}
\hline \multicolumn{2}{|c|}{ SATISFACTION } \\
\hline Variable & Job Satisfaction \\
\hline Role ambiguity & $-0.48 I^{*}$ \\
\hline Role conflict & $-0.352 *$ \\
\hline
\end{tabular}

Job Satisfaction and Turnover Intentions

A negative correlation was observed between job satisfaction and turnover intentions $(r=-0.470)$, significant at the 0.01 level (Table 6). Thus, strong support was obtained for the hypothesised relationship between job satisfaction and turnover intentions $\left(\mathrm{H}_{10}\right)$. As job satisfaction increases, there are stronger intentions to remain within the firm, thus the desire to leave the firm decreases.

\section{TABLE 6: PEARSON CORRELATION COEFFICIENT FOR JOB SATISFACTION AND TURNOVER INTENTIONS}

\begin{tabular}{lc}
\hline Variable & Turnover Intentions \\
\hline Job satisfaction & $-0.470 *$ \\
* Correlation is significant at the 0.01 level ( I-tailed).
\end{tabular}




\section{Relationships between Variables}

To test multiple relationships between the variables, multiple regressions and stepwise regressions were carried out with job-related tension as the dependent variable in the first regression, job satisfaction as the dependent variable in the second regression, and turnover intentions as the dependent variable in the third regression. Tests for multicollinearity, normality and the existence of outliers were undertaken and deemed the data suitable for regression analysis. The significant models that emerged from the stepwise regressions are outlined in Table 7.

TABLE 7: STEPWISE REGRESSION ANALYSIS

\begin{tabular}{|c|c|c|c|c|c|}
\hline Dependent Variable & $\begin{array}{l}\text { Regression } \\
\text { Coefficient }\end{array}$ & $\begin{array}{l}\text { Standard } \\
\text { Error }\end{array}$ & $\begin{array}{c}\text { Beta } \\
\text { Coefficient }\end{array}$ & Sig.t & VIF \\
\hline \multicolumn{6}{|l|}{ Job-Related Tension } \\
\hline Role overload - qualitative & 0.284 & 0.081 & 0.342 & 0.001 & 1.996 \\
\hline Role overload - quantitative & 0.256 & 0.076 & 0.326 & 0.001 & 1.937 \\
\hline Role ambiguity & 0.348 & 0.113 & 0.218 & 0.003 & 1.042 \\
\hline \multicolumn{6}{|c|}{$R^{2}=0.464, F=32.3 \mathrm{I} \mathrm{I}$, Signif. $F=0.000$} \\
\hline \multicolumn{6}{|l|}{ Job Satisfaction } \\
\hline Role ambiguity & -0.528 & 0.126 & -0.351 & 0.000 & 1.174 \\
\hline Career development & -0.210 & 0.052 & -0.337 & 0.000 & 1.174 \\
\hline \multicolumn{6}{|c|}{$R^{2}=0.328, F=27.63$, Signif. $F=0.000$} \\
\hline \multicolumn{6}{|l|}{ Turnover Intentions } \\
\hline Job satisfaction & -0.508 & 0.115 & -0.379 & 0.000 & $1.14 \mid$ \\
\hline Role conflict & 0.457 & 0.150 & 0.260 & 0.003 & $1.14 \mid$ \\
\hline \multicolumn{6}{|c|}{$R^{2}=0.280, F=21.996$, Signif. $F=0.000$} \\
\hline
\end{tabular}

In the first stepwise regression, with job-related tension as the dependent variable, a significant model has emerged $\left(F=32.311, p<0.005, R^{2}=0.464\right)$ with significant variables identified as being role overload (both quantitative and qualitative) and role ambiguity. The findings from the multiple regressions show that in the case of job-related tension no statistically significant variables were identified as having made a unique contribution to job-related tension; moreover a combined effect contributed to the outcome $\left(F=10.296, p<0.005, R^{2}=0.495\right)$.

In the second stepwise regression, with job satisfaction as the dependent variable, a number of models emerged with the final model including role ambiguity, career development, exam pressure and qualitative role overload as variables predicting job satisfaction. The findings regarding exam pressure and qualitative role overload were not statistically significant, however, therefore the model with significant variables is shown in Table $7\left(F=27.63, p<0.005, R^{2}=0.328\right)$. The findings show that role ambiguity and career development concerns are the greatest predictors of job satisfaction for this sample of trainee accountants. The multiple regression findings are consistent with stepwise in this instance, with career development $($ Beta $=-0.359, p=0.001)$ and role ambiguity (Beta $=-0.357, p<0.0005)$ being identified as significant variables contributing to job satisfaction with no other 
variables being identified as statistically significant predictors $(F=7.101, p<0.005$, $\left.R^{2}=0.403\right)$.

Finally, a significant model has emerged using stepwise regression with turnover intentions as a dependent variable $\left(F=21.996, p<0.005, R^{2}=0.28\right)$ where job satisfaction and role conflict are identified as significant predictors of turnover intentions. The multiple regression findings support that of stepwise regressions with job satisfaction (Beta $=-0.346, p=0.001)$ and, to a lesser extent, role conflict (Beta $=0.283, p=$ $0.004)$ contributing to turnover intentions $\left(F=5.163, p<0.005, R^{2}=0.376\right)$.

\section{Background Variables}

$T$-tests and ANOVA tests were performed to determine if there are any differences in variables depending on demographic characteristics. $T$-test results show a significant difference in job-related tension scores between male and female respondents $(t=-2.878, p=0.005)$, where female respondents experienced higher levels of job-related tension, but no differences between the two groups in terms of job satisfaction and turnover intentions. Those respondents who worked in practice displayed significantly lower job satisfaction than their counterparts working in industry $(t=-3.166, p=0.002)$ but no difference in terms of job-related tension or turnover intentions. The non-parametric Mann-Whitney $U$ tests support the findings of the parametric tests undertaken above.

\section{Qualitative Comments}

In the space provided at the end of the questionnaire respondents were asked to comment on job problems or stress in work; only 20 respondents from a sample size of 116 completed this section. The respondents listed long working hours, poor pay, heavy workload and intimidating colleagues as contributing to stress in the workplace. A common theme was the difficulty of balancing all commitments with limited study leave for exams. The responses here support the evidence from the quantitative analysis, that exam pressure is a significant source of anxiety for Irish trainee accountants. One respondent commented:

I find that working in industry whilst attending lectures at night time is quite stressful and hard especially when you have no option but to work late as strict deadlines have to be met thus affecting your study and lecture patterns.

Another comment by a trainee chartered accountant was:

Accounting is what I've always wanted to do but sometimes when you try to juggle having a life, attending lectures, study and work on very bad money, you wonder what it's all for, you see people with limited qualifications earning three times as much as I am and have their evenings and weekends to themselves, its disillusioning, to say the least. 


\section{ANALYSIS OF FINDINGS}

\section{Job Stressors}

The mean scores displayed in Table 3 indicate the ranking of job stressors and the frequency with which they contribute to job stress. The findings show that exam pressure is the highest ranked job stress variable experienced 'often' by the respondents in their roles as trainee accountants. The remaining job stressors are deemed to be experienced by the respondents sometimes or occasionally with role conflict, role ambiguity, role overload (both qualitative and quantitative) and a dominant supervisor impacting on stress 'sometimes'; and career development, a passive supervisor and role underload (qualitative and quantitative) contributing to stress 'occasionally'. Pearson correlation coefficients reported in Table 4 show that there is a strong relationship between role overload and job-related tension, consistent with prior literature (for example, Collins and Killough, 1989, 1992; Gavin and Dileepan, 2002), with qualitative overload ranking highest, followed by quantitative role overload. Role conflict, role ambiguity and career development concerns are also found to have significant positive relationships with job-related tension, supporting prior literature (Lysonski, 1985; Gavin and Dileepan, 2002). This study contributes to the literature further by identifying additional factors that are significantly related to job-related tension, namely the impact of a dominant or passive supervisor and exam pressure. In addition, this study finds no statistical support for the relationship between role underload and job-related tension, which conflicts with earlier findings by Gaertner and Ruhe (1981) with regard to junior accountants. Thus, trainee accountants in Ireland either do not feel that they are being 'underused' at work or experiencing 'low job scope' or they do experience these feelings but are not stressed by them.

Given these findings, we return to the first objective of this paper, which is to establish the root causes of occupational stress for trainee accountants in Ireland. The findings in Table 3 and 4 identify that eight of the ten stressors examined in this study are deemed to correlate with job-related tension. Multiple regressions undertaken confirm that these stressors account for 49.5 per cent of variation in job-related tension but no statistically significant variables were identified as having a unique contribution to job-related tension; rather there is a combined effect. In contrast, stepwise regression indicates that the combination of role overload (both qualitative and quantitative) and role ambiguity are quite strongly correlated to job-related tension. The findings regarding role overload are consistent with prior research but the impact of role ambiguity, whilst being recognised in prior literature as impacting job-related tension in non-accounting firms (Lysonski, 1985), has not to date been found to have had a significant impact in accounting firms (Senatra, 1980; Rebele and Michaels, 1990). 
Kelly and Barrett

\begin{abstract}
Job Satisfaction
The average score for the job satisfaction measure on a scale from 1 to 7 was 4.25. This is very similar to the score obtained by Sweeney and Boyle (2005), who used three of the four items used in this study to measure job satisfaction and reported a mean score of 4.22. Almost one-third (31.9 per cent) of respondents in this study indicated that they were only satisfied with their job occasionally or less than occasionally, which contrasts with 36.7 per cent of respondents in the Sweeney and Boyle (2005) study. Consistent with prior literature, both role conflict and role ambiguity were found to be negatively related to job satisfaction. The individual variables identified as contributing to job-related tension were examined for their impact on job satisfaction and found to explain 40.3 per cent of the variation in job satisfaction, with career development concerns and role ambiguity significantly contributing to job dissatisfaction (Table 7). These findings support those of Senatra (1980) with regard to role ambiguity but add to the literature by demonstrating the impact of career progress concerns on job satisfaction.
\end{abstract}

\title{
Turnover Intentions
}

The average score for turnover intentions was 5.13 on a scale from 1 to 7 . The mean scores for turnover intentions within two, five and ten years were 3.65, 5.47 and 6.28 respectively. These results support the view that in the short term trainee accountants have the immediate objectives of gaining a qualification and acquiring experience and thus may be less reluctant to depart their firms but, in general, there is a long-term expectation of moving on, which is not unexpected for trainee accountants. The individual variables identified as contributing to job-related tension and job satisfaction were examined for their impact on turnover intentions and found to explain 37.6 per cent of the variation in turnover intentions, with job dissatisfaction and role conflict significantly contributing to turnover intentions (Table 7). The findings with regard to job satisfaction and turnover intentions are consistent with prior literature (Rasch and Harrell, 1990; Dole and Schroeder, 2001) whilst the impact of role conflict on turnover intentions is consistent with Sorensen and Sorensen (1972).

\section{CONCLUSIONS}

A number of limitations should be considered before drawing conclusions from the study's findings. First, random selection was not engaged in to select the individuals who participated in this study. As a result, it is not known with certainty if the study participants are representative of all Irish trainee accountants. Second, social desirability may have had an impact on the responses. To reduce this limitation, the survey was completed anonymously by respondents. Third, the timing of distribution of the survey may have had an impact on particular responses. The survey was distributed in early summer prior to many of the trainee accountants sitting their exams and, resultantly, respondents may have reported higher levels of stress as a result of exam pressure. Fourth, some of the scales to measure job stressors had only one or two items resulting in difficulty in assessing their reliability 
using Cronbach's alpha (exam pressure and dominant or passive supervisor). Their inclusion in this study represents an exploratory start at recognising the impact of variables not measured in prior research. Further research can extend their use by lengthening the scales to allow for greater measurement of reliability.

Subject to these limitations, a number of important implications can be drawn from this research. The findings in this study provide support for earlier research with regard to the relationship between role stress and job-related tension, job satisfaction and turnover intentions (Senatra, 1980; Rebele and Michaels, 1990; Fisher, 2001). Role conflict and role ambiguity do significantly impact on job-related tension, which in turn leads to job dissatisfaction, which can impact on staff turnover intentions. The findings, however, are not that simplistic. A number of individual role stressors have been found to impact on job-related tension (as previously identified in prior literature): role overload (qualitative and quantitative), role conflict, role ambiguity and career development concerns; and some new role stressors were tested and found to have an impact, namely exam pressure and having either a dominant or passive supervisor (the dominant supervisor being identified as having a greater impact on job-related tension than his/her passive counterpart). In particular, role overload (both quantitative and qualitative), a dominant supervisor and exam pressure had the strongest correlation with job-related tension.

Multiple regression analysis finds that the variables' impact on job-related tension are not significant on their own but are in a combined way, with stepwise regression identifying role overload (qualitative and quantitative) and role ambiguity having a significant impact. Regression analysis also identifies role ambiguity as having a significant impact on job satisfaction, along with career development concerns, and job satisfaction and role conflict impact significantly on turnover intentions.

From the employer's perspective, the issue of role ambiguity is important in the current study in that it significantly impacts on both job-related tension and job satisfaction. Milbourn (2006, p. 44) defines a job as ambiguous if 'the worker has unclear work goals, procedures, and responsibilities and may be uncertain about his or her authority'. Employers could address role ambiguity by clearly defining and documenting goals, procedures and responsibilities and ensuring that staff are adequately trained to perform the tasks they are expected to undertake. In addition to role ambiguity, employers need to address the impact of role overload (qualitative and quantitative) on job-related tension. Qualitative role overload could be addressed through further training (as outlined above) and perhaps the use of supervisors in a mentoring capacity. The mentoring aspect of a supervisor's role could assist in reducing the perception of supervisors as 'dominant' and aid trainees in mapping out their career path, thus reducing career development concerns. Mentors may also be able to provide trainee accountants with the opportunity to discuss their concerns with regard to role conflict and perhaps reduce the levels of stress associated with this issue. The leadership and mentoring role of supervisors has been found by Sweeney and Boyle (2005) to be significantly positively associated with job satisfaction in Irish trainee accountants. Quantitative role overload requires that employers address the workload of their trainees. Roslender, Stevenson and Kahn $(2006$, p. 3) suggest that 'perhaps the single most important 
Kelly and Barrett

practice that employers can put in place to minimise employee stress is to ensure that there are sufficient numbers of employees to perform the work that needs to be done'. This is particularly relevant during periods of exam preparation, where exam pressure has been identified as significantly correlating with job-related tension in this study. The accounting professional bodies could consider their role in reducing stress levels for their student members by reviewing the structure of the examination process and consider allowing for credit to be applied for continuous assessment. This continuous assessment approach could be linked to practical learning outcomes that could also assist in a reduction in qualitative role overload and better prepare students for the demands of the profession they are entering into.

The findings of this study indicate that there is further scope for research in this area. First, future research utilising more qualitative means of data collection such as interviews would be very beneficial. This would allow an examination of a wide range of additional variables that contribute to occupational stress. Second, the present study measures the outcomes of stress through the use of self-reporting. Similar to the thoughts of Collins and Killough (1992), the authors of the current study suggest future research should supplement these subjective measures of stress outcomes with physiological (medical) measures of mental and physical distress. Finally, from a methodological point of view, it may be fruitful for future researchers to conduct longitudinal studies to enable hypotheses concerning causality to be tested.

Reducing job-related tension, increasing job satisfaction and reducing turnover intentions of Irish trainee accountants is by no means a simple chore for employers in today's pressure-cooker business environment. However, the authors in the current study highlight the importance of adequate staffing levels, training, mentoring, documented procedures and clearly defined roles in reducing role ambiguity, role overload, role conflict, the impact of a dominant supervisor or a passive supervisor, career development concerns and exam pressure. By managing the quantity of workloads effectively and focusing on improving the training environment, employers should find a reduction in the level of occupational stress, increased job satisfaction and reduced turnover intentions.

\section{ENDNOTES}

1 The views expressed are solely those of the authors, and not necessarily shared by Ernst \& Young. 


\section{APPENDIX: RELEVANT EXTRACTS FROM QUESTIONNAIRE}

Please note that this information is strictly for research purposes only.

\section{Respondent Profile}

Age:

What year of training are you in?

Sex: $\quad$ Female $\square \quad$ Male

Are you working: $\quad$ In practice $\square \quad$ In industry

If working in practice, are you employed by:

Big four firm $\square \quad$ Non-big four firm $\square$

If working in industry, what sector are you employed in?

Membership body with which you are taking exams: ACCA, CIMA, CPA, ICAI, etc.

Have you entered into a contract? $\quad$ Yes $\square$ No $\square$

If so, what duration is your contract?

\section{Section A}

With respect to the effect your job has on your health, please indicate your agreement or disagreement with each statement below by circling the appropriate response according to the following scale:

$I$ = Strongly disagree, 2 = Disagree, 3 = Slightly disagree, 4 = Slightly agree, $5=$ Agree, $6=$ Strongly agree

\begin{tabular}{|l|llllll|}
\hline My job tends to directly affect my health & I & 2 & 3 & 4 & 5 & 6 \\
\hline I work under a great deal of tension & I & 2 & 3 & 4 & 5 & 6 \\
\hline I have felt nervous as a result of my job & I & 2 & 3 & 4 & 5 & 6 \\
\hline $\begin{array}{l}\text { Job worries sometimes get me down } \\
\text { physically }\end{array}$ & I & 2 & 3 & 4 & 5 & 6 \\
\hline $\begin{array}{l}\text { Problems associated with my job have } \\
\text { kept me awake at night }\end{array}$ & I & 2 & 3 & 4 & 5 & 6 \\
\hline I often wonder whether it's all worth it & I & 2 & 3 & 4 & 5 & 6 \\
\hline $\begin{array}{l}\text { I have worried, after making a decision, } \\
\text { whether I did the right thing }\end{array}$ & I & 2 & 3 & 4 & 5 & 6 \\
\hline $\begin{array}{l}\text { I often 'take my job home with me' in the } \\
\text { sense that I think about it when doing } \\
\text { other things }\end{array}$ & I & 2 & 3 & 4 & 5 & 6 \\
\hline
\end{tabular}


Kelly and Barrett

\section{Section B}

Please indicate your answer to the following statements by circling the most appropriate where $I=$ Very false, 2 = False, 3 = Neither true nor false, $4=$ True and 5 = Very true

\begin{tabular}{|c|c|c|c|c|c|}
\hline $\begin{array}{l}\text { I feel certain about how much authority I have at my } \\
\text { firm }\end{array}$ & I & 2 & 3 & 4 & 5 \\
\hline Clear, planned goals and objectives exist for my job & 1 & 2 & 3 & 4 & 5 \\
\hline $\begin{array}{l}\text { I know that I have divided my time properly at my } \\
\text { firm }\end{array}$ & 1 & 2 & 3 & 4 & 5 \\
\hline I know what my responsibilities are at my firm & I & 2 & 3 & 4 & 5 \\
\hline I know exactly what is expected of me at my firm & 1 & 2 & 3 & 4 & 5 \\
\hline $\begin{array}{l}\text { Explanation is clear of what has to be done at my } \\
\text { firm }\end{array}$ & I & 2 & 3 & 4 & 5 \\
\hline $\begin{array}{l}\text { I have to do things that should be done differently at } \\
\text { my firm }\end{array}$ & I & 2 & 3 & 4 & 5 \\
\hline $\begin{array}{l}\text { I receive assignments without the staff to complete } \\
\text { them at my firm }\end{array}$ & I & 2 & 3 & 4 & 5 \\
\hline $\begin{array}{l}\text { I have to disobey a rule or policy in order to carry } \\
\text { out job assignments }\end{array}$ & I & 2 & 3 & 4 & 5 \\
\hline $\begin{array}{l}\text { I work with two or more groups who operate quite } \\
\text { differently at my firm }\end{array}$ & I & 2 & 3 & 4 & 5 \\
\hline $\begin{array}{l}\text { I receive incompatible requests from two or more } \\
\text { people at my firm }\end{array}$ & I & 2 & 3 & 4 & 5 \\
\hline $\begin{array}{l}\text { I do things that are acceptable by one person and } \\
\text { not acceptable by others at my firm }\end{array}$ & I & 2 & 3 & 4 & 5 \\
\hline $\begin{array}{l}\text { I receive assignments without adequate resources } \\
\text { and materials to execute them at my firm }\end{array}$ & I & 2 & 3 & 4 & 5 \\
\hline I work on unnecessary things at my firm & 1 & 2 & 3 & 4 & 5 \\
\hline
\end{tabular}

\section{$[\ldots]$}

\section{Section D}

Please indicate the frequency with which the following conditions are a source of stress for you by circling the appropriate number:

I = If the condition is never a source of stress

$2=$ If it is rarely a source of stress

$3=$ If it is occasionally a source of stress

$4=$ If it is sometimes a source of stress

$5=$ If it is often a source of stress

$6=$ If it is usually a source of stress

$7=$ If it is always a source of stress 
The Leading Causes and Potential Consequences of Occupational Stress

\begin{tabular}{|l|lllllll|}
\hline The demands for work quality made upon me are unreasonable & $\mathrm{I}$ & 2 & 3 & 4 & 5 & 6 & 7 \\
\hline My assigned tasks are sometimes too difficult and/or complex & $\mathrm{I}$ & 2 & 3 & 4 & 5 & 6 & 7 \\
\hline Tasks seem to be getting more and more complex & $\mathrm{I}$ & 2 & 3 & 4 & 5 & 6 & 7 \\
\hline $\begin{array}{l}\text { The organisation expects more of me than my skills and/or } \\
\text { abilities provide }\end{array}$ & $\mathrm{I}$ & 2 & 3 & 4 & 5 & 6 & 7 \\
\hline $\begin{array}{l}\text { I have insufficient time to keep abreast of all current } \\
\text { developments in my work }\end{array}$ & $\mathrm{I}$ & 2 & 3 & 4 & 5 & 6 & 7 \\
\hline $\begin{array}{l}\text { I feel that I have too heavy a workload that I can't possibly finish } \\
\text { during the normal day of work }\end{array}$ & $\mathrm{I}$ & 2 & 3 & 4 & 5 & 6 & 7 \\
\hline I am attending meetings that take up too much time & $\mathrm{I}$ & 2 & 3 & 4 & 5 & 6 & 7 \\
\hline I have insufficient time to carry out all of my tasks & $\mathrm{I}$ & 2 & 3 & 4 & 5 & 6 & 7 \\
\hline I lack the proper opportunities to advance in this organisation & $\mathrm{I}$ & 2 & 3 & 4 & 5 & 6 & 7 \\
\hline $\begin{array}{l}\text { If I want to get promoted I have to look for a job with another } \\
\text { organisation }\end{array}$ & $\mathrm{I}$ & 2 & 3 & 4 & 5 & 6 & 7 \\
\hline I am hurting my career progress by staying with this organisation & $\mathrm{I}$ & 2 & 3 & 4 & 5 & 6 & 7 \\
\hline $\begin{array}{l}\text { I have few opportunities to grow and learn new knowledge and } \\
\text { skills in my job }\end{array}$ & $\mathrm{I}$ & 2 & 3 & 4 & 5 & 6 & 7 \\
\hline I feel that I am at a standstill in my career & $\mathrm{I}$ & 2 & 3 & 4 & 5 & 6 & 7 \\
\hline I feel that I have too light a workload & $\mathrm{I}$ & 2 & 3 & 4 & 5 & 6 & 7 \\
\hline $\begin{array}{l}\text { I have job demands that interfere with other activities (family, } \\
\text { recreation, etc.) }\end{array}$ & $\mathrm{I}$ & 2 & 3 & 4 & 5 & 6 & 7 \\
\hline $\begin{array}{l}\text { I am undertaking lectures in the evenings and/or at weekends } \\
\text { which interfere with other activities }\end{array}$ & $\mathrm{I}$ & 2 & 3 & 4 & 5 & 6 & 7 \\
\hline $\begin{array}{l}\text { Studying for exams interferes with other activities (family, } \\
\text { recreation, etc.) }\end{array}$ & $\mathrm{I}$ & 2 & 3 & 4 & 5 & 6 & 7 \\
\hline I have a dominant/demanding supervisor/manager & $\mathrm{I}$ & 2 & 3 & 4 & 5 & 6 & 7 \\
\hline $\begin{array}{l}\text { I have a passive supervisor/manager who gives little feedback on } \\
\text { the work I perform }\end{array}$ & $\mathrm{I}$ & 2 & 3 & 4 & 5 & 6 & 7 \\
\hline $\begin{array}{l}\text { My assigned tasks are sometimes too easy and/or unchallenging/ } \\
\text { undemanding and thus I tend to get bored easily at work }\end{array}$ & $\mathrm{I}$ & 2 & 3 & 4 & 5 & 6 & 7 \\
\hline
\end{tabular}

[...]

\section{Section F}

Please indicate your answer to the following statements by circling the most appropriate where $I=$ strongly disagree and 7 = strongly agree

\begin{tabular}{|l|lllllll|}
\hline $\begin{array}{l}\text { I plan to remain with my current organisation for at least } \\
\text { two more years }\end{array}$ & I & 2 & 3 & 4 & 5 & 6 & 7 \\
\hline $\begin{array}{l}\text { I plan to remain with my current organisation for at least } \\
\text { five more years }\end{array}$ & I & 2 & 3 & 4 & 5 & 6 & 7 \\
\hline $\begin{array}{l}\text { I plan to remain with my current organisation for at least } \\
\text { ten more years }\end{array}$ & I & 2 & 3 & 4 & 5 & 6 & 7 \\
\hline
\end{tabular}


Kelly and Barrett

\section{Section G}

Please indicate your answer to the following questions by ticking the most appropriate box.

Q: Which one of the following shows how much of the time you feel satisfied with your job?

I. Never

2. Seldom

3. Occasionally

4. About half of the time

5. A good deal of the time

6. Most of the time

7. All of the time

Q: Choose one of the following statements which best tells how well you like your job:

I. I hate it

2. I dislike it

3. I don't like it

4. I am indifferent to it

5. I like it

6. I am enthusiastic about it

7. I love it

Q: Which one of the following best tells how you feel about changing your job?

I. I would quit this job at once if I could

2. I would take almost any other job in which I could earn as much as I am earning now

3. I would like to change both my job and my occupation

4. I would like to exchange my present job for another one

5. I am not eager to change my job, but I would do so if I could get a better job

6. I cannot think of any jobs for which I would exchange

7. I would not exchange my job for any other

Q: Which one of the following shows how you think you compare with other people?

I. No one dislikes his/her job more than I dislike mine

2. I dislike my job much more than most people dislike theirs

3. I dislike my job more than most people dislike theirs

4. I like my job about as well as most people like theirs

5. I like my job better than most people like theirs

6. I like my job much better than most people like theirs

7. No one likes his/her job better than I like mine 
The Leading Causes and Potential Consequences of Occupational Stress

\section{Section $\mathbf{H}$}

Please provide any additional comments on job problems or stress in your work in the space provided below.

Thank you for your time and cooperation in completing this questionnaire.

\section{REFERENCES}

Arnold, H. and Feldman, D. (1982). A Multivariate Analysis of the Determinants of Turnover, Journal of Applied Psychology, Vol. 7, No. 3, pp. 350-360.

Bamber, E.M., Snowball, D. and Tubbs, R.M. (1989). Audit Structure and Its Relation to Role Conflict and Role Ambiguity: An Empirical Investigation, The Accounting Review, Vol. 64, No. 2, pp. 285-299.

Briggs, S.R. and Cheek, J.M. (1986). The Role of Factor Analysis in the Development and Evaluation of Personality Scales, Journal of Personality, Vol. 54, No. 1, pp. 106-148.

Burke, R.J. (1976). Occupational Stresses and Job Satisfaction, The Journal of Social Psychology, Vol. 100, No. 2, pp. 235-244.

Carcello, J.V., Copeland, J.E., Hermanson, R.H. and Turner, D.H. (1991). A Public Accounting Career: The Gap between Student Expectations and Accounting Staff Experiences, Accounting Horizons, Vol. 5, No. 3, pp. 1-11.

Choo, F. (1986). Job Stress, Job Performance, and Auditor Personality Characteristics, Auditing: A Journal of Practice and Theory, Vol. 5, No. 2, pp. 17-34.

Cluskey, G.R. and Vaux, A. (1997). Is Seasonal Stress a Career Choice of Professional Accountants?, Journal of Employment Counseling, Vol. 34, No. 1, pp. 7-19.

Collins, K.M. and Killough, L.N. (1989). Managing Stress in Public Accounting, Journal of Accountancy, Vol. 167, No. 5, pp. 92-97.

Collins, K.M. and Killough, L.N. (1992). An Empirical Examination of Stress in Public Accounting, Accounting, Organizations and Society, Vol. 17, No. 6, pp. 535-547.

Cooper, C.L., Cooper, R.D. and Eaker, L.H. (1988). Living with Stress, London: Penguin Books.

Cooper, D.R. and Emory, C.W. (1995). Business Research Methods, fifth edition, Chicago, IL: Irwin.

Cronbach, L.J. (1951). Coefficient Alpha and the Internal Structure of Tests, Psychometrika, Vol. 16, No. 3, pp. 297-334.

Dole, C. and Schroeder, R.G. (2001). The Impact of Various Factors on the Personality, Job Satisfaction and Turnover Intentions of Professional Accountants, Managerial Auditing Journal, Vol. 16, No. 4, pp. 234-245.

Donnelly, D.P., Quirin, J.J. and O'Bryan, D. (2003). Auditor Acceptance of Dysfunctional Audit Behavior: An Explanatory Model Using Auditors' Personal Characteristics, Behavioral Research in Accounting, Vol. 15, pp. 87-110.

Ehlen, C.R., Cluskey, G.R. and Rivers, R.A. (2000). Reducing Stress from Workload Compression: Coping Strategies that Work in CPA Firms, The Journal of Applied Business Research, Vol. 16, No. 1, pp. 9-13.

Fisher, R.T. (2001). Role Stress, the Type A Behavior Pattern, and External Auditor Job Satisfaction and Performance, Behavioral Research in Accounting, Vol. 13, pp. 143-170. 
Kelly and Barrett

Fogarty, T.J., Singh, J., Rhoads, G.K. and Moore, R.K. (2000). Antecedents and Consequences of Burnout in Accounting: Beyond the Role Stress Model, Behavioral Research in Accounting, Vol. 12, pp. 31-67.

French, J.R.P. and Caplan, R.D. (1973). Organizational Stress and Individual Strain, in A.J. Morrow (ed.), The Failure of Success, New York, NY: Amacom.

Gaertner, J. and Ruhe, J. (1981). Job-Related Stress in Public Accounting, Journal of Accountancy, Vol. 151, No. 6, pp. 68-74.

Gavin, T.A. and Dileepan, P. (2002). Stress!! Analyzing the Culprits and Prescribing a Cure, Strategic Finance, Vol. 84, No. 5, pp. 51-55.

Gmelch, W.H., Lovich, N.P. and Wilke, P.K. (1984). Sources of Stress in Academe, Research in Higher Education, Vol. 20, No. 4, pp. 471-490.

Gregson, T. and Wendell, J. (1994). Role Conflict, Role Ambiguity, Job Satisfaction and the Moderating Effect of Job-Related Self-Esteem: A Latent Variable Analysis, Journal of Applied Business Research, Vol. 10, No. 2, pp. 106-114.

Gregson, T., Wendell, J. and Aono, J. (1994). Role Ambiguity, Role Conflict, and Perceived Environmental Uncertainty: Are the Scales Measuring Separate Constructs for Accountants?, Behavioral Research in Accounting, Vol. 6, pp. 144-159.

Harrell, A., Chewning, E. and Taylor, M. (1986). Organizational-Professional Conflict and the Job Satisfaction and Turnover Intentions of Internal Auditors, Auditing: A Journal of Practice and Theory, Vol. 5, No. 2, pp. 109-121.

Haskins, M.E., Baglioni, A.J. and Cooper, C.L. (1991). An Investigation of the Sources, Moderators and Psychological Symptoms of Stress among Audit Seniors, Contemporary Accounting Research, Vol. 6, No. 2, pp. 361-385.

Hobfoll, S.E. (1988) The Ecology of Stress, New York, NY: Hemisphere Publishing.

Hoppock, R. (1935). Job Satisfaction, New York, NY: Harper and Row.

Hyndman, N. (1994). Accounting Practice: An Empirical Study of Practitioners' Experiences and Students' Expectations, Irish Accounting Review, Vol. 1, No. 1, pp. 95-112.

Ivancavich, J.M. and Matteson, M.T. (1980). Stress and Work: A Managerial Perspective, New York, NY: McGraw Hill.

Kahn, R.L., Wolfe, D.M., Quinn, R.P., Snoek, J.D. and Rosenthal, R.A. (1964). Organizational Stress: Studies in Role Conflict and Ambiguity, New York, NY: Wiley.

Labovitz, S. (1970). The Assignment of Numbers to Rank Order Categories, American Sociological Review, Vol. 35, No. 3, pp. 515-524.

Larson, L. (2004). Internal Auditors and Job Stress, Managerial Auditing Journal, Vol. 19, No. 9, pp. 1119-1130.

Libby, R. (1983). Comments on Weick, The Accounting Review, Vol. 58, No. 2, pp. 370-374.

Lysonski, S. (1985). A Boundary Theory Investigation of the Product Manager's Role, Journal of Marketing, Vol. 49, No. 1, pp. 26-40.

McNichols, C.W., Stahl, M.J. and Manley, T.R. (1978). A Validation of Hoppock's Job Satisfaction Measure, Academy of Management Journal, Vol. 21, No. 4, pp. 737-742.

Milbourn, G. (2006). Teaching the Job Stress Audit to Business School Students: Causes, Measurement, Reduction, The Journal of American Academy of Business, Cambridge, Vol. 8, No. 2, pp. 44-50.

Pallant, J. (2007). SPSS Survival Manual, New York, NY: McGraw Hill.

Rasch, R.H. and Harrell, A. (1990). The Impact of Personal Characteristics on the Turnover Behavior of Accounting Professionals, Auditing: A Journal of Practice and Theory, Vol. 9, No. 2, pp. 90-102.

Rebele, J.E. and Michaels, R.E. (1990). Independent Auditors' Role Stress: Antecedent, Outcome, and Moderating Variables, Behavioral Research in Accounting, Vol. 2, pp. 124-153. 
Reichel, A. and Neumann, Y. (1993). Work Stress, Job Burnout, and Work Outcomes in a Turbulent Environment: The Case of Israeli Executives, International Studies of Management $\mathcal{E}$ Organization, Vol. 23, No. 3, pp. 75-96.

Rizzo, J., House, J. and Lirtzman, S. (1970). Role Conflict and Ambiguity in Complex Organizations, Administrative Science Quarterly, Vol. 15, No. 2, pp. 150-163.

Roslender, R., Stevenson, J. and Kahn, H. (2006). Employee Wellness as Intellectual Capital: An Accounting Perspective, Journal of Human Resource Costing \& Accounting, Vol. 10, No. 1, pp. 48-64.

Sanders, J.C. and Fulks, D.L. (1995). Stress and Stress Management in Public Accounting, CPA Journal, Vol. 65, No. 8, pp. 46-50.

Senatra, P.T. (1980). Role Conflict, Role Ambiguity, and Organizational Climate in a Public Accounting Firm, The Accounting Review, Vol. LV, No. 4, pp. 594-603.

Siegel, P.H. and Reinstein, A. (2001). An Exploratory Study of Mentor Relationships in Large CPA Firms, Scandinavian Journal of Management, Vol. 17, No. 4, pp. 421-436.

Smith, K. and Everly, G.S. (1990). An Intra- and Inter-Occupational Analysis of Stress among Accounting Academicians, Behavioral Research in Accounting, Vol. 2, pp. 154-173.

Smith, K.J., Everly, G.S. and Johns, T.R. (1993). The Role of Stress Arousal in the Dynamics of the Stressor-to-Illness Process among Accountants, Contemporary Accounting Research, Vol. 9, No. 2, pp. 432-449.

Snead, K. and Harrell, A. (1991). The Impact of Psychological Factors on the Job Satisfaction of Senior Auditors, Behavioral Research in Accounting, Vol. 3, pp. 85-96.

Sorensen, J.E., Rhode, J.G. and Lawler, E.E. (1973). The Generation Gap in Public Accounting, The Journal of Accountancy, Vol. 36, No. 6, pp. 42-50.

Sorensen, J.E. and Sorensen, T.L. (1972). Comparison of 1965 and 1970 Organizational and Professional Profiles and Migration Plans of Large-Firm CPAs, in T.J. Bums (ed.), Behavioral Experiments in Accounting, Columbus, OH: Ohio State University.

Sweeney, B. and Boyle, B. (2005). Supervisory Actions, Job Satisfaction and Turnover Intentions of Irish Trainee Accountants, Irish Accounting Review, Vol. 12, No. 2, pp. 47-73.

Xie, J.L. and Johns, G. (1995). Job Scope and Stress: Can Job Scope Be too High?, Academy of Management Journal, Vol. 38, No. 5, pp. 1288-1309. 